\title{
PRODUÇÃO DA LARANJA NO PRINCIPAL CINTURÃO CITRÍCOLA BRASILEIRO: perfil e a concorrência com outras culturas
}

\section{ORANGE PRODUCTION IN THE MAIN BRAZILIAN CITRUS BELT: profile and competition with other cultures}

\author{
Gerônimo Guerreiro Neto \\ Mestrado pela Universidade Estadual Paulista “Júlio de Mesquita Filho", Jaboticabal, SP. \\ gneto1968@hotmail.com \\ Sérgio Rangel Fernandes Figueira \\ Doutor em Economia e professor do Departamento de Economia, Administração e Educação da \\ Universidade Estadual Paulista "Júlio de Mesquita Filho", Jaboticabal, SP. \\ sergio.rf.figueira@unesp.br
}

\begin{abstract}
Resumo
O objetivo deste trabalho foi identificar dentro do principal cinturão citrícola brasileiro - estado de São Paulo e o Triangulo/Sudoeste Mineiro - a percepção do produtor de laranja com relação a substituição da cultura por outra dentro de sua propriedade. Em 922 propriedades, estratificadas em número de plantas: até 20.000; 20.001 a 100.000 e mais que 100.000, divididas em 12 regiões e 5 setores, foram realizadas 260 entrevistas - uma em cada propriedade. Com $93 \%$ de nível de confiança e $5 \%$ de erro amostral, foi identificado que: a produção de laranja dentro da região pesquisada, é composta em sua maioria por produtores ainda de pequeno porte (menor que 20.000 plantas), com baixa produtividade por hectare, e pouca sofisticação nos métodos de controle dos custos de produção. A pesquisa identificou equilíbrio na presença da laranja com outras culturas nas propriedades, além do que, o produtor tem a percepção que a laranja, foi nas últimas 3 safras (2017, 2018 e 2019), mais rentável que as culturas presentes em sua região, e, por isso, não pretende, substituir a cultura cítrica por outra. Em caso de troca, a cana- deaçúcar é a cultura preferida por parte dos produtores - sobretudo nas regiões ao centro e norte do cinturão citrícola brasileiro.
\end{abstract}

Palavras- chave: Setor Norte. Noroeste. Sul. Sudoeste. Centro.

\begin{abstract}
The objective of this work was to identify within the main Brazilian citrus belt - state of São Paulo and the Triangle / Southwest Mineiro - the perception of the orange producer in relation to the replacement of the crop by another within his property. In 922 properties stratified in number of plants: up to 20,$000 ; 20,001$ to 100,000 and more than 100,000 , divided into 12 regions and 5 sectors. 260 interviews were conducted - one at each property. With 93\% confidence level and 5\% sampling error, it was identified that: orange production within the surveyed region, is mostly composed of small-scale producers, with
\end{abstract}


low productivity per hectare, and little sophistication in methods control of production costs. The research identified balance in the presence of oranges with other crops on the properties, in addition, the producer has the perception that the orange, in the last 3 harvests (2017 2018 e 2019), was more profitable than the crops present in his region, and, therefore, he replaces the citrus culture with another. In case of exchange, sugar cane is the preferred crop on the part of producers - especially in the central and northern regions of the Brazilian citrus belt.

Keywords: North Sector. Northwest. South. Southwest. Center.

\section{Introdução}

Entre as frutas cítricas espalhadas pelo mundo, a laranja, com 73 milhões de toneladas, é a mais importante, seguida pelas tangerinas, mandarins, clementinas, satsumas, com 50 milhões de toneladas somadas, e por último, os limões e limas, com 19,6 milhões de toneladas. A laranja está presente no continente africano, na Europa, onde tem presença na Espanha, Itália e Portugal; na Ásia está presente na China; e nas Américas, a laranja tem grande importância no Brasil, Estados Unidos e México (FAO, 2018).

Segundo especialistas, os pomares cítricos mais produtivos atualmente, estão nas regiões de clima tropical e subtropical, destacando-se o Brasil, Estados Unidos, México, China e África do Sul (PULCINE; SIMÃO; MANOLESCU, 2017).

Enquanto Brasil (São Paulo) e Estados Unidos (Flórida) utilizam mais de 70\% das laranjas que produzem para a fabricação de sucos, México e China, em sua maioria, vendem as frutas para o consumo in natura. Na Espanha, mais da metade das laranjas têm como destino a exportação (NEVES et al., 2010; UAGRO, 2013). Países como: Argentina, Itália, Espanha e África do Sul, são tradicionais produtores de laranja com foco no mercado de fruta in natura (PAULILLO; NEVES, 2015). O Brasil, notoriamente é um país que faz uso da laranja na produção de suco. Em 2017, o país respondeu por mais de $50 \%$ da produção e $76 \%$ do comércio mundial de suco de laranja, cujos destinos principais do suco foram Europa e os Estados Unidos, com respectivamente 64,5\% e 21,6\% do volume comercializado (CITRUS BR, 2018).

O Brasil é o maior produtor mundial de laranja, com área destinada à colheita de 595,4 mil hectares em 2018, sendo 376,6 mil hectares somente no estado de São Paulo, principal estado produtor brasileiro (IBGE,2020). Dentro do Brasil a principal região 
produtora de laranja fica concentrada em São Paulo e no Triângulo/Sudoeste Mineiro (Cinturão Citrícola), com área total de 407,7 mil hectares em 2020 (FUNDECITRUS, 2020). Apesar de toda relevância que a produção de laranja representa dentro do cinturão citrícola, sobretudo no estado São Paulo, a cultura vem passando por transformações em seus indicadores de produção. Entre 1995 a 2018, a área colhida dentro do estado paulista encolheu $63,2 \%$, de 865,8 mil para 376,6 mil hectares (IBGE,2020). Concomitante a perda de área, o cinturão citrícola também apresenta queda do número de propriedades que produzem esta importante fruta cítrica nos últimos anos. Entre 1995 a 2018, o número de propriedades com laranja recua 6 vezes, de 35.883 para no máximo 5.882, e o tamanho médio das propriedades com destino na produção de laranja salta de 24,1 para 70,4 hectares. Assim, menos propriedades com laranja, e as que permanecem estão maiores (CATI, 2018; FUNDECITRUS, 2018). Existe tendência de queda no número de propriedades com laranja no Estado de São Paulo, sendo que, um dos motivos estaria relacionado ao aumento nos custos de produção, bem como a presença de culturas substitutas (concorrentes), em especial a cana-de-açúcar (NEVES e LOPES, 2005). A área ocupada no cultivo de frutíferas diminuiu no Estado de São Paulo de 1996 para 2008, devido à retração da principal cultura, a laranja, sendo a cana de açúcar a principal cultura substituta (FELIPE,2008; DE CAMARGO et al, 2011). Vários fatores contribuíram para a o avanço da produção da cana-de-açúcar - principal cultura substituta da laranja - em regiões tradicionalmente cultivadas com a cultura cítrica, sobretudo pragas e doenças (Greening) - que encareceram os custos de produção (GALINARI, 2015; MAÇORANO 2017; ERPEN et al., 2018). A área colhida de uma das principais culturas substitutas da laranja em São Paulo, a cana-de-açúcar avançou de 2,44 para 5,58 milhões de hectares $(+128,7 \%)$ no período de1997 a 2016 (Figura 1). 
Figura 1: Evolução da área colhida de cana e laranja no Estado de São Paulo

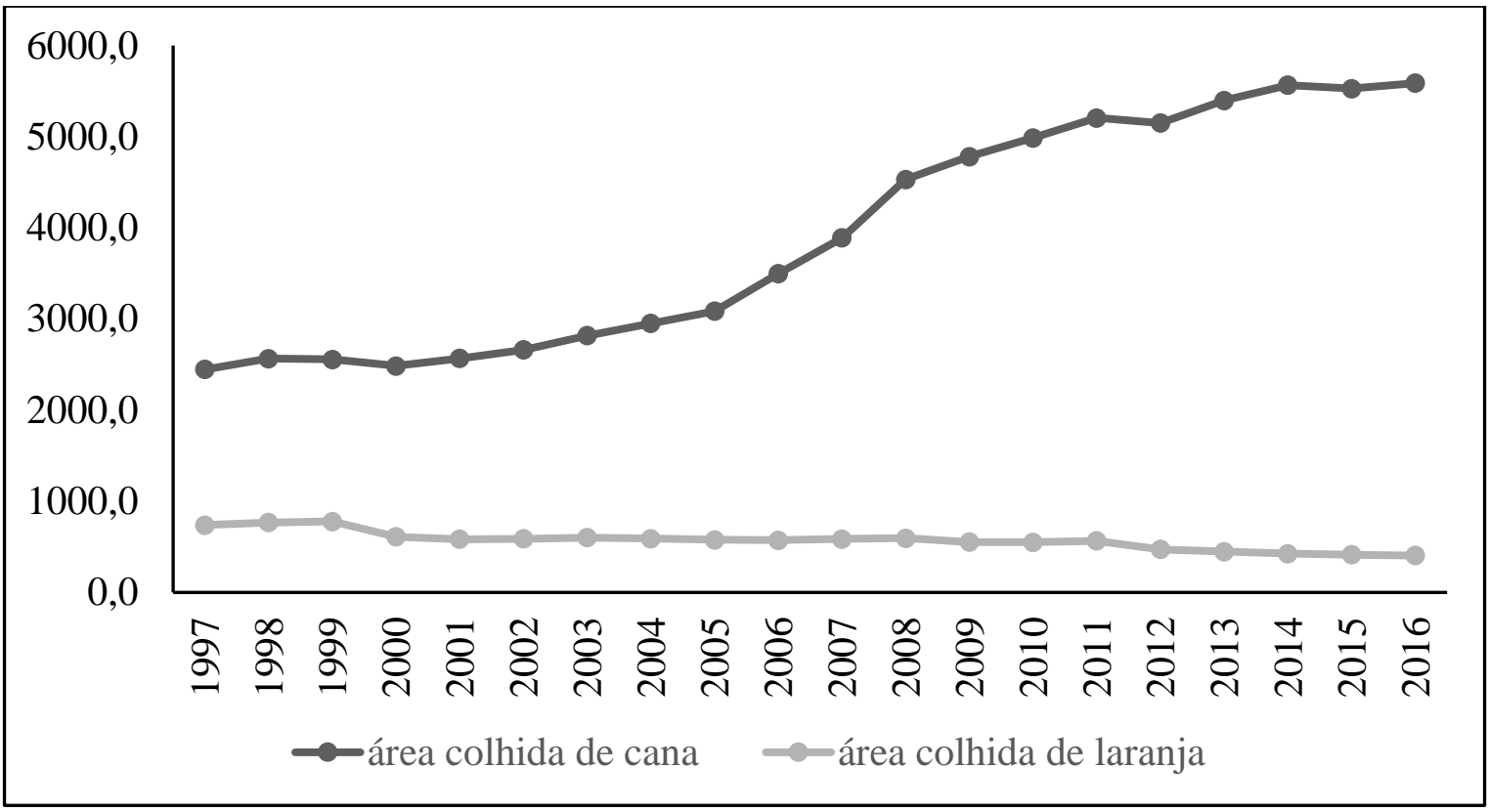

Fonte: Adaptado de dados do IBGE (2018).

Entre 1995 e 2015 ocorreu grande elevação na produção canavieira paulista, passando de aproximadamente 158 milhões de toneladas na safra 1995/96 para aproximadamente 368 milhões de toneladas na safra 2015/2016 (OLIVEIRA, 2017), impulsionada, principalmente pelo aumento da área cultivada e preços, com baixa contribuição do efeito rendimento, evidenciado pela elevada contribuição do efeito substituição na expansão da área cultivada, onde, nesse período, a lavoura canavieira expandiu em 2,49 milhões de hectares no Estado de São Paulo, substituindo lavouras temporárias, permanentes e pastagens (CAMARA; CALDARELLI, 2016).

A pesquisa tem importância para a economia do estado de São Paulo e o Triângulo Mineiro onde, a citricultura é uma das cadeias do agronegócio com maior geração de renda e com maior índice de empregos por hectare, principalmente porque toda a colheita, que se estende por cerca de dez meses, é feita de forma manual (FUNDECTRUS, 2019). Outras grandes culturas cultivadas nesta região, como café, soja, milho, e cana de açúcar possuem colheita quase que totalmente mecanizadas. A pesquisa possui relevância acadêmica, de políticas públicas, e gerencial, por ajudar a compreender às mudanças na dinâmica da produção da laranja dentro do cinturão citrícola e, assim, ajudar nas ações seja de governo, ou na iniciativa privada, no sentido da manutenção de uma citricultura competitiva, porém justa e sustentável, não só econômica, mas também social. A 
obtenção de dados primários e posterior análise dará significado à importância da pesquisa.

O objetivo geral da pesquisa foi identificar junto ao produtor de laranja do cinturão citrícola a possibilidade de troca da cultura por outra atividade agrícola na propriedade. Para atingir este objetivo geral, foi identificado os seguintes objetivos específicos: a) produtividade da laranja na propriedade; b) além da laranja, identificar a presença de outra cultura na propriedade; c) intensão de plantio de outra cultura, além da laranja na propriedade; d) rentabilidade da laranja frente a outras culturas concorrentes da região; e) possibilidade da troca da laranja por outra cultura na mesma área; f) culturas preferenciais em substituição a laranja por região do cinturão.

\section{Material e métodos}

A pesquisa, realizada no segundo semestre de 2019, utilizou a aplicação de entrevistas estruturadas em propriedades citrícolas com laranja dentro do Cinturão Citrícola. A região onde se localiza no Brasil, a maior concentração de propriedades que se destinam à produção comercial de laranja, abrangendo municípios do estado de São Paulo e alguns de Minas Gerais situados nas regiões do Triângulo Mineiro e Sudoeste deste estado, é denominado de Cinturão Citrícola (FUNDECITRUS,2020). A figura 2 representa a localização geográfica das propriedades pesquisadas dentro do cinturão citrícola.

As questões das entrevistas, todas fechadas, foram aplicadas pessoalmente ou por telefone com o produtor ou o gestor da propriedade, cada uma refletindo a realidade de uma propriedade com laranja. Todas as entrevistas foram aplicadas mediante o uso de um aparelho de "tablet" no formato digitalizado. Cada profissional de campo da empresa, treinado, e de posse deste equipamento, fez a entrevista ao respondente em sua visita de rotina, ou em visita agendada na propriedade, como também por telefone. Ao término da aplicação da pesquisa, gerou-se um banco de dados em Excel, posteriormente tabulado e analisado. A população a ser estudada foi de propriedades com laranja presentes no Estado de São Paulo e no Triângulo/Sudoeste Mineiro - Cinturão Citrícola, pertencentes a uma carteira de cadastro de uma empresa processadora de suco de laranja, em uma população total de 922 propriedades). 
Figura 2. Localização das propriedades pesquisadas dentro do Cinturão Citrícola

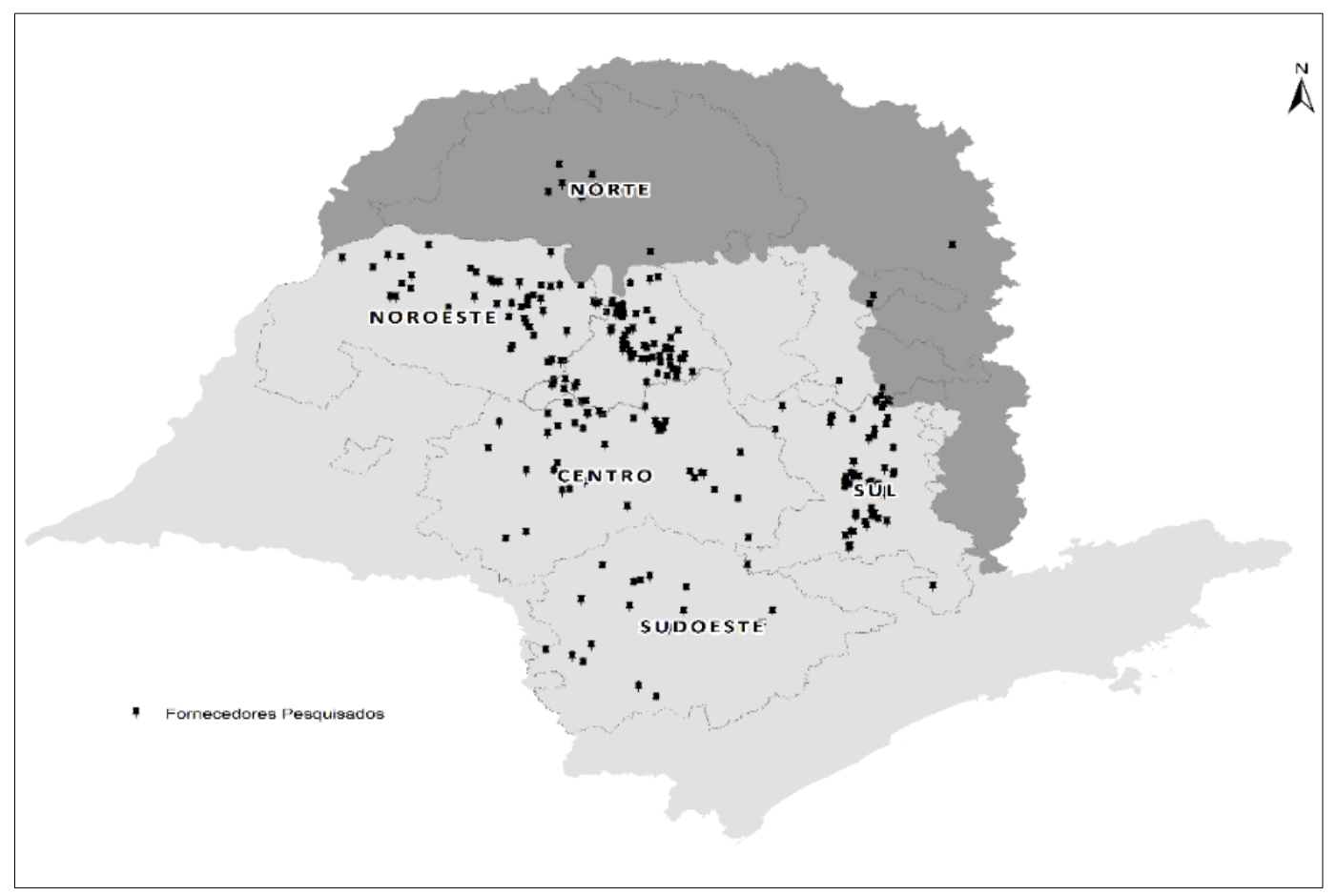

Fonte: Elaboração própria (2021).

O plano amostral utilizado foi o plano estratificado com distribuição proporcional das amostras selecionadas dentro dos estratos (BUSSAB \& MORETTIN,2002). Esse plano amostral foi selecionado com intuito de se obter uma amostra mais representativa e abrangente da população em questão. Os estratos (três) utilizados seguiram o número de plantas de laranja que cada propriedade possui; até 20.000 plantas; de 20.001 a 100.000 plantas, e mais que 100.000 plantas. A divisão das regiões foi escolhida de acordo com as regiões geográficas definidas pelo (FUNDECITRUS, 2020), pelo qual o cinturão citrícola tem 5 Setores, que envolvem 12 regiões, da seguinte forma: Setor Norte (regiões de Bebedouro e Triângulo Mineiro); Setor Noroeste (regiões de Votuporanga e São José do Rio Preto); Setor Centro (regiões de Matão, Duartina e Brotas); Setor Sul (Regiões de regiões de Porto Ferreira e Limeira), e Setor Sudoeste (regiões de Itapetininga e Avaré). As 12 regionais foram estratificadas igualmente (3 estratos) em quantidade de plantas para garantir uma melhor representatividade dos imóveis dentro do cinturão, bem como uma classificação por tamanho da propriedade.

A distribuição proporcional das amostras respeitou a distribuição da população 
analisada (922 propriedades com laranja). Exemplo: Se o estrato X possui $5 \%$ dos imóveis da população, então será alocado 5\% das amostras para aquele estrato. A escolha dos imóveis selecionados dentro de cada estrato foi feita de maneira aleatória, permitindo-se inferência sobre proporção de determinada característica observada nas respostas. Foi realizada a estimação de proporção populacional com população finita, com erro amostral de 5\% e nível de confiança de 95\% segundo a Equação (1).

$$
\mathrm{n}=\frac{\mathrm{N}^{*} \hat{\mathrm{p}}^{*} \widehat{\mathrm{q}}^{*}\left(\mathrm{Z}_{\alpha / 2}\right)^{2}}{\hat{\mathrm{p}}^{*} \hat{\mathrm{q}}^{*}\left(\mathrm{Z}_{\alpha / 2}\right)^{2}+(\mathrm{N}-1) * \mathrm{E}^{2}}
$$

Onde $N=922$ é o número total da população de fornecedores, $E=0,05$ é o erro amostral, $Z \alpha 2$ / é o valor crítico da distribuição normal correspondente ao grau de confiança desejado e p e q são as probabilidades de indivíduos pertencerem e não pertencerem a categoria. Como os valores de p e q não são conhecidos adotaremos uma abordagem conservadora e substituiremos a expressão $\hat{p} * q^{\wedge}$ por 0,25 segundo (Bussab \& Morettin,2002). Segundo a equação 1 o número ideal de amostras para pesquisa seriam 272 questionários respondidos, porém por motivos de indisponibilidade ou recusa de alguns respondentes só foi possível realizar 260 questionários. Com essa diminuição, o nível de confiança desejado foi afetado e fixando o número de amostra realizado, o número da população e o erro amostral de $5 \%$ na Equação 1, obtemos um nível de confiança de $93 \%$, portando a pesquisa realizada com 260 questionários se manteve com 5\% de erro amostral, mas teve uma redução no nível de confiança de 95\% para $93 \%$.

\section{Resultados e discussões}

Quanto ao perfil de tamanho das propriedades pesquisadas, de 260 questionários respondidos pelos produtores, 159 , ou $61 \%$, é referência a propriedades com laranja de pequeno porte - com até 20.000 plantas de laranja; 75 ou $29 \%$ são propriedades com tamanho intermediário, - entre 20.001 a 100.000 plantas - e somente 26 ou $10 \%$ são grandes propriedades - com mais de 100.000 plantas de laranja (Figura 3). 
Figura 3: Questionários respondidos por tamanho de propriedade (em número plantas)

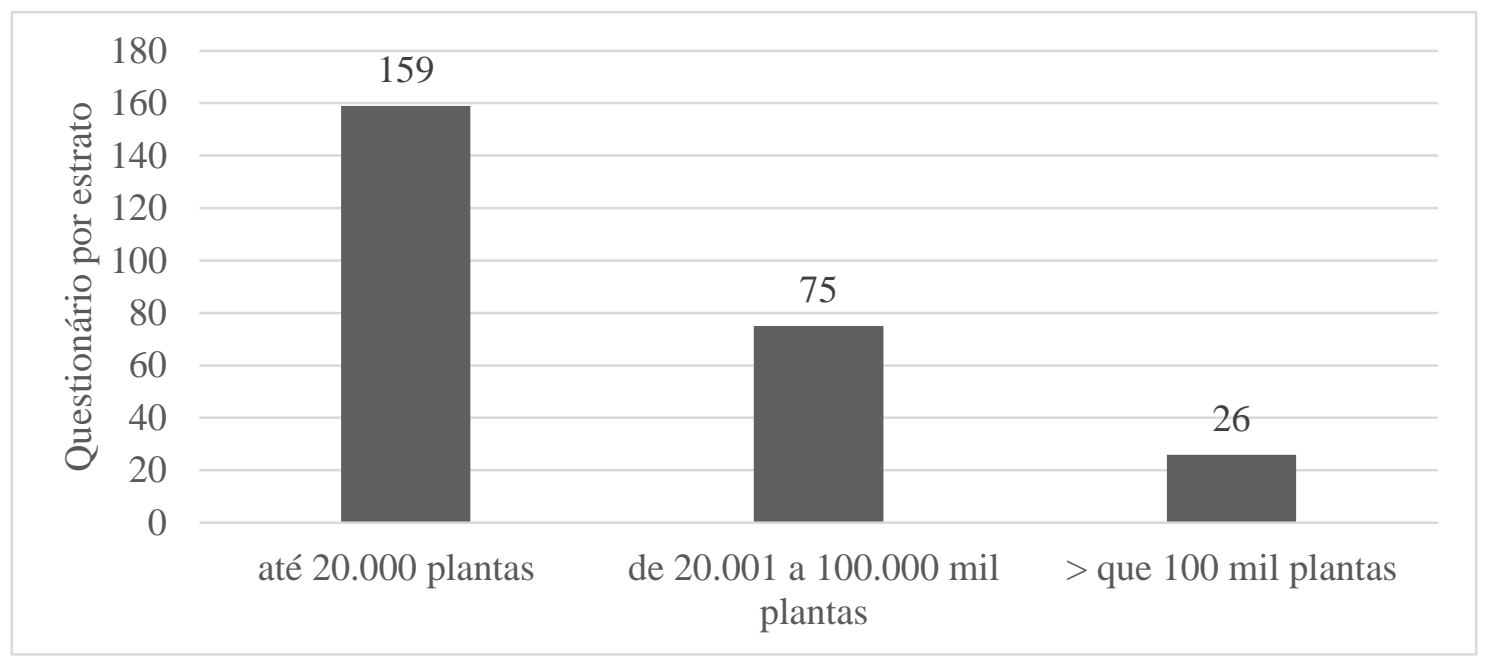

Fonte: Elaboração própria (2021).

A pesquisa está em conformidade com os dados do inventário de plantas de laranja dentro do cinturão citrícola efetuado pelo Fundecitrus, onde 77,6\% das propriedades com laranja em 2018 possuíam até 20.000 plantas (FUNDECITRUS,2018). Este modelo de produção com pequenas propriedades citrícolas produzindo laranja, gerando e distribuindo renda, se apresenta como uma alternativa para uma citricultura mais sustentável no âmbito social.

A pesquisa captou a produtividade em caixas de laranja de $40,8 \mathrm{~kg}$ por hectare nas propriedades, por estrato produtivo, nas últimas 3 safras (2017, 2018 e 2019), na percepção dos produtores. Pela pesquisa, propriedades com até 20.000 plantas, $58 \%$ produzem até 800 caixas por hectare. Somente $10 \%$ das propriedades deste estrato tem produção maior que 1.101 caixas por hectare. Nenhuma propriedade de pequeno porte produziu 1.400 caixas por hectare (Figura 4). 
Figura 4: Faixas de produção em propriedades até 20.000 plantas.

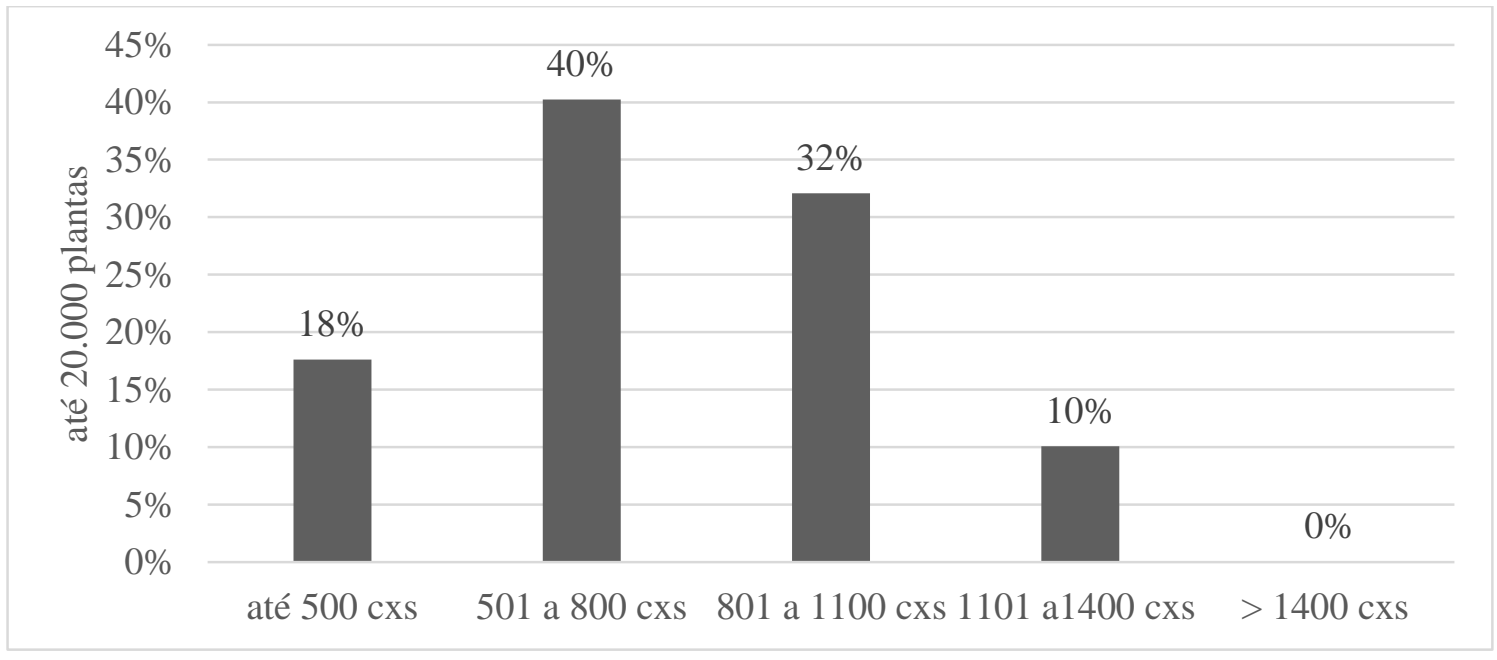

Fonte: Elaboração própria (2021).

Nas propriedades de tamanho intermediário (20.001a100.000 plantas), 83\% das produtividades estão distribuídas em uma faixa ampla (501 a 1.400 caixas por hectare). Importante considerar que algumas propriedades (8\%), apresentam produtividades altíssimas (mais que 1.400 caixas por hectare) (Figura 5).

Figura 5: Faixas de produção em propriedades de 20.001 a 100.000 mil plantas

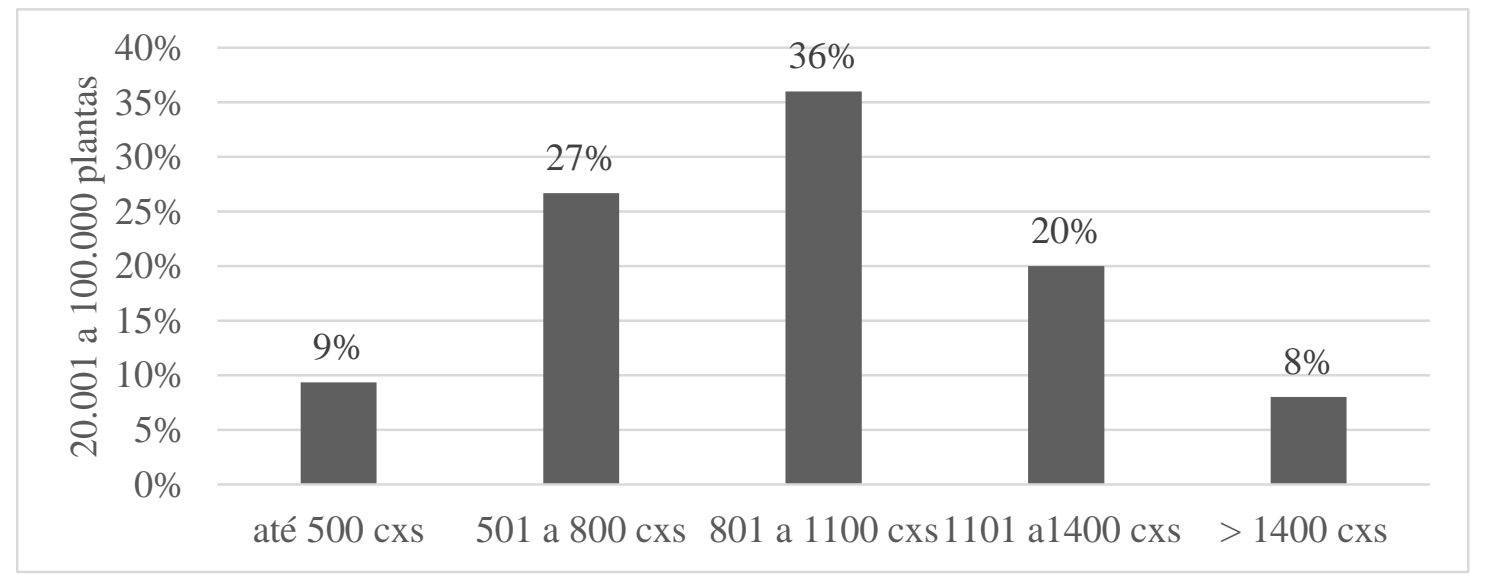

Fonte: Elaboração própria (2021).

Quando se analisa as propriedades grandes (maiores que 100.000 plantas), identifica-se que as produtividades estão concentradas entre 801 a 1.400 caixas por hectare - com $85 \%$ das propriedades nesta faixa. Ressaltar que $35 \%$ destas propriedades apresentam produtividades maiores que 1.101 caixas por hectare, maior percentual nesta 
faixa de produtividade entre todos os estratos (Figura 6), o que corrobora com Neves e Lopes (2005), que relatam que imóveis de grande porte apresentam altas produtividades quando comparados com os menores - resultado de mais investimento e tecnologia no processo produtivo.

Figura 6: Faixas de produção em propriedades com mais de 100.000 mil plantas.

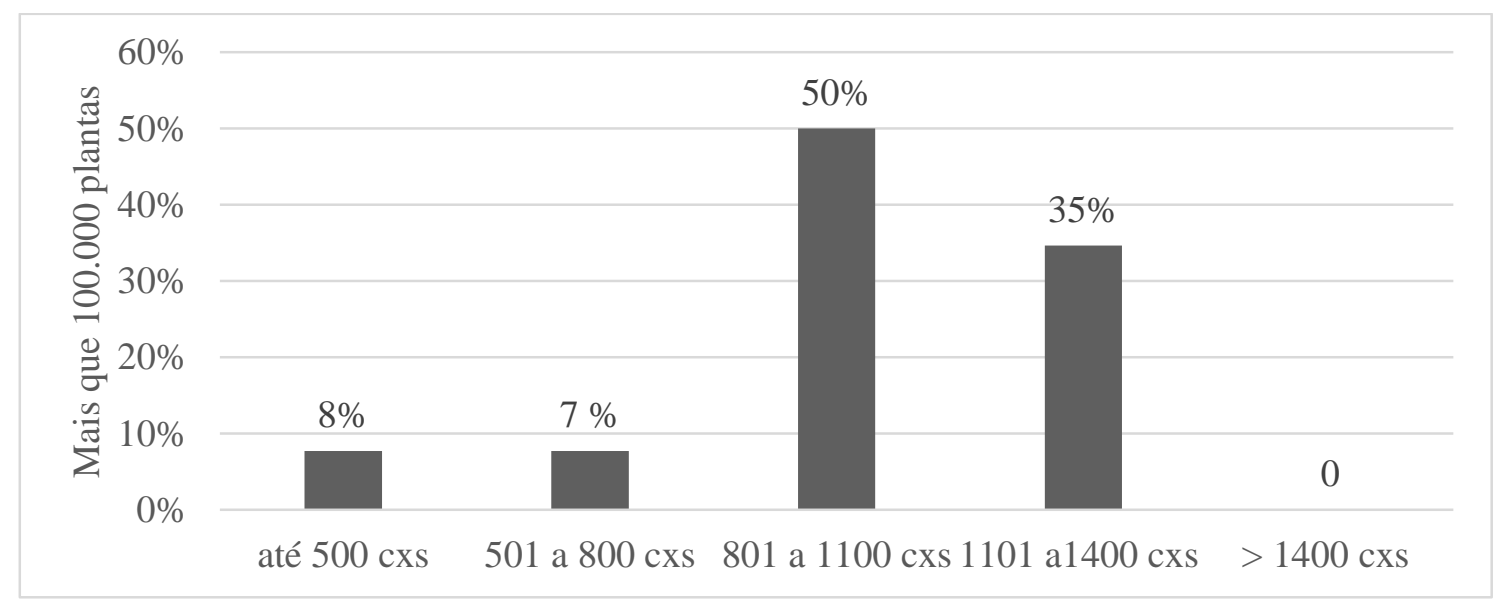

Fonte: Elaboração própria (2021).

Pelos gráficos analisados, identifica-se que existe uma tendência das propriedades maiores em produzirem mais laranja por unidade de área - maior produtividade por hectare. Se observa um percentual maior de propriedades dentro dos estratos com produtividades acima de 800 caixas por hectare. Para efeito comparativo, dentro do cinturão citrícola, na estimativa de safra 2019/2020, a produtividade média em caixas por hectare variou de 924 caixas de 40,8 kg no Setor Noroeste à 1227 caixas no Setor Sudoeste, respectivamente menor e maior produtividade por hectare nos setores dentro do cinturão citrícola (FUNDECITRUS, 2019). Pela pesquisa, propriedades menores com menos de 20.000 plantas - apresentam $58 \%$ de produtividades inferiores a 800 caixas por hectare, e as maiores (mais que 100.000 plantas), somente $15 \%$ das propriedades estão nesta faixa de produtividade.

Produtividade é um ótimo recurso na diluição e diminuição dos custos de produção por caixa de laranja produzida, sendo uma variável que tem um certo controle por parte do citricultor (NEVES et al., 2010). A produtividade reflete a eficiência produtiva das propriedades. Na medida em que a produção de caixas de laranja por área (hectare) é maior, significa que o citricultor consegue utilizar melhor seus recursos e 
insumos em um determinado espaço, traduzindo este desempenho em maior produção por unidade de área. Na medida que a produtividade de uma propriedade é muito baixa, a atividade pode não renumerar o suficiente para o citricultor permanecer em sua atividade.

A pesquisa captou dos produtores seus esforços com relação aos investimentos em seu pomar nas últimas 3 safras (2017,2018 e 2019). Ao serem indagados sobre se fizeram investimentos no intuito de obter o máximo de produtividade, $60 \%$ disseram que certamente sim, e $30 \%$ provavelmente sim. Somente $1 \%$ dos produtores mostraram certeza em não fazer investimentos à altura de máxima produção (Figura 7). Na medida em que o produtor se diz propenso a fazer investimentos para produzir mais, significa que tem um bom grau de satisfação com a cultura que cultiva no momento.

Figura 7: Fez Investimentos nas últimas safras para ter o máximo de produção?

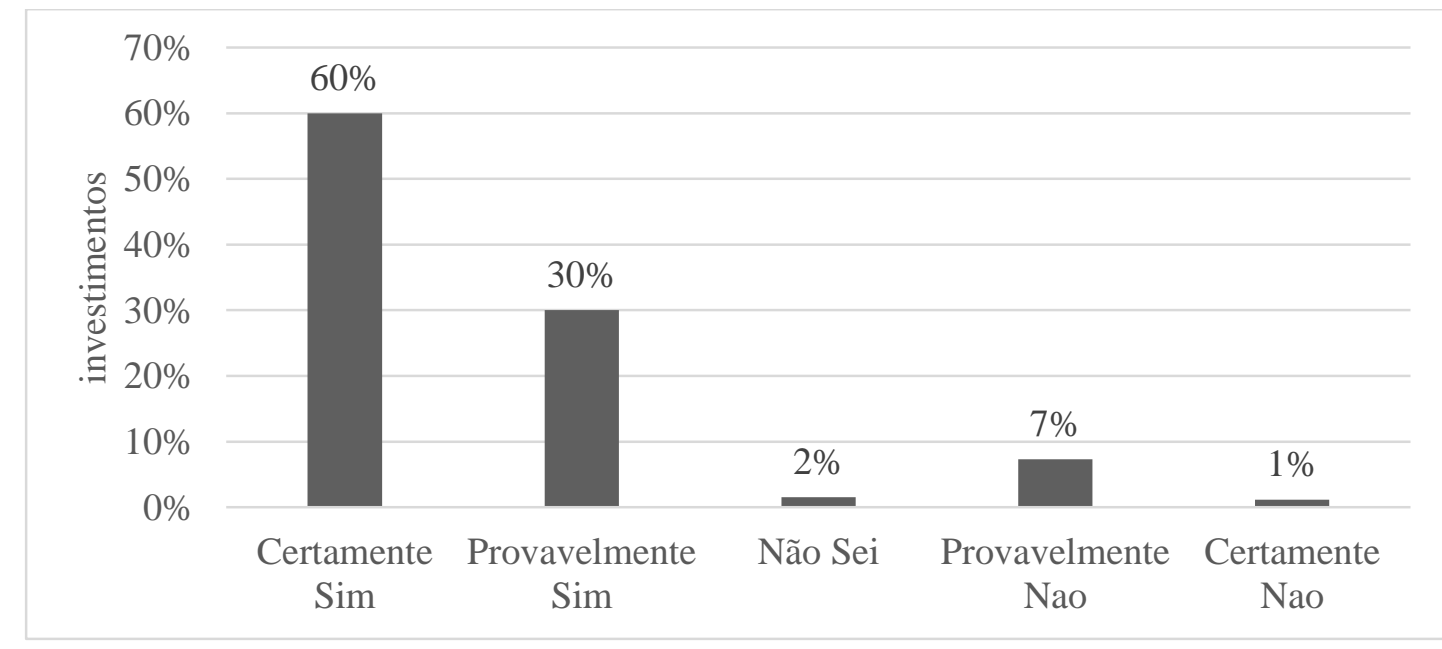

Fonte: Elaboração própria (2021).

Maiores investimentos tendem a refletir maiores produtividades, contudo, como analisado em produtividades por tamanho de propriedade (Figuras 4; 5 e 6), identifica-se que várias propriedades produzem ao máximo 500 caixas de laranja de 40,8 kg por hectare, sobretudo as de menor tamanho (Figura 4). Dessa forma, ao fazer o máximo investimento, não significa necessariamente que obterá alta performance de produtividade, visto o dinamismo que envolve a cultura da laranja. Quando os produtores foram questionados se apresentam outra atividade agrícola dentro da propriedade, além da laranja, as respostas demostram um perfil equilibrado. De 260 produtores questionados, $52 \%$ (135) apresentam outra atividade agrícola dentro da fazenda, e $48 \%$ (125) só possuem a cultura da laranja (Figura 8). 
Figura 8: Presença de outra atividade na propriedade além da laranja?

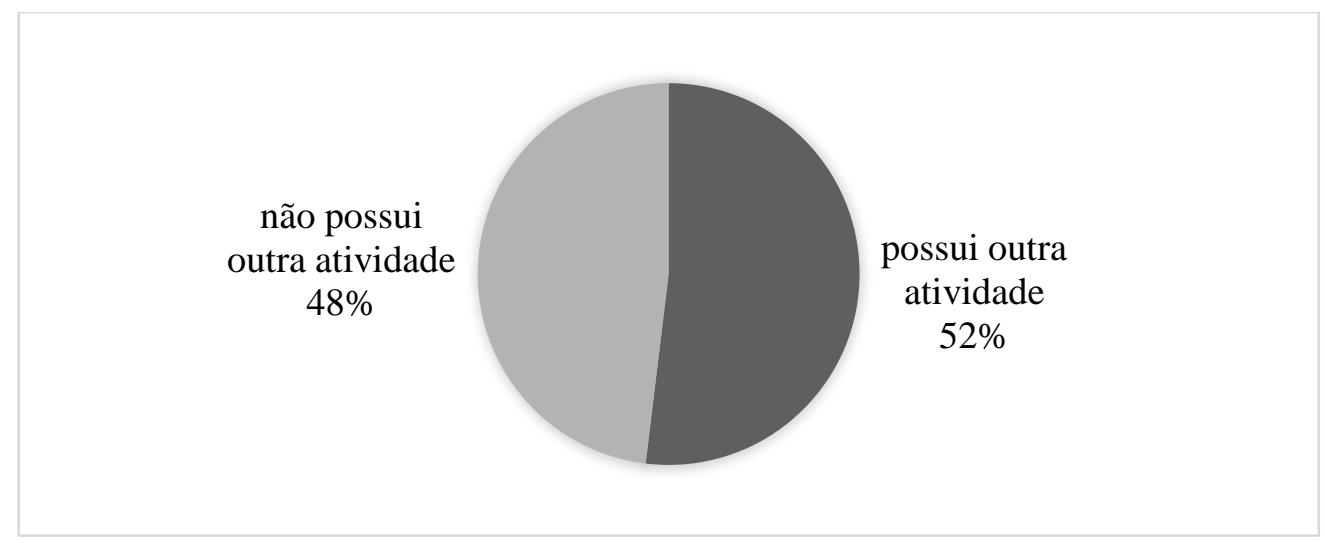

Fonte: Elaboração própria (2021).

O equilíbrio na distribuição de culturas agrícolas dentro de uma propriedade rural apresenta alguns aspectos a serem ponderados. Possuir mais de uma cultura dentro de uma propriedade rural minimiza os riscos com relação as oscilações de preços e adversidades climáticas, promovendo uma menor dependência da receita da monocultura.

Mais que ter o perfil das culturas nas propriedades, a pesquisa procurou identificar em investimentos futuros se o produtor que só possui laranja em sua propriedade, pretende diversificar sua produção, implantando uma outra cultura. Como resposta, $61 \%$ dos produtores dizem que provavelmente e certamente não implantarão outra cultura (Figura 9). Uma parcela muito pequena, (10\%) dos respondentes estão certos de produzir ao mesmo tempo outra cultura na propriedade.

Figura 9. Tem intensão de plantio de outra cultura além da laranja na propriedade?

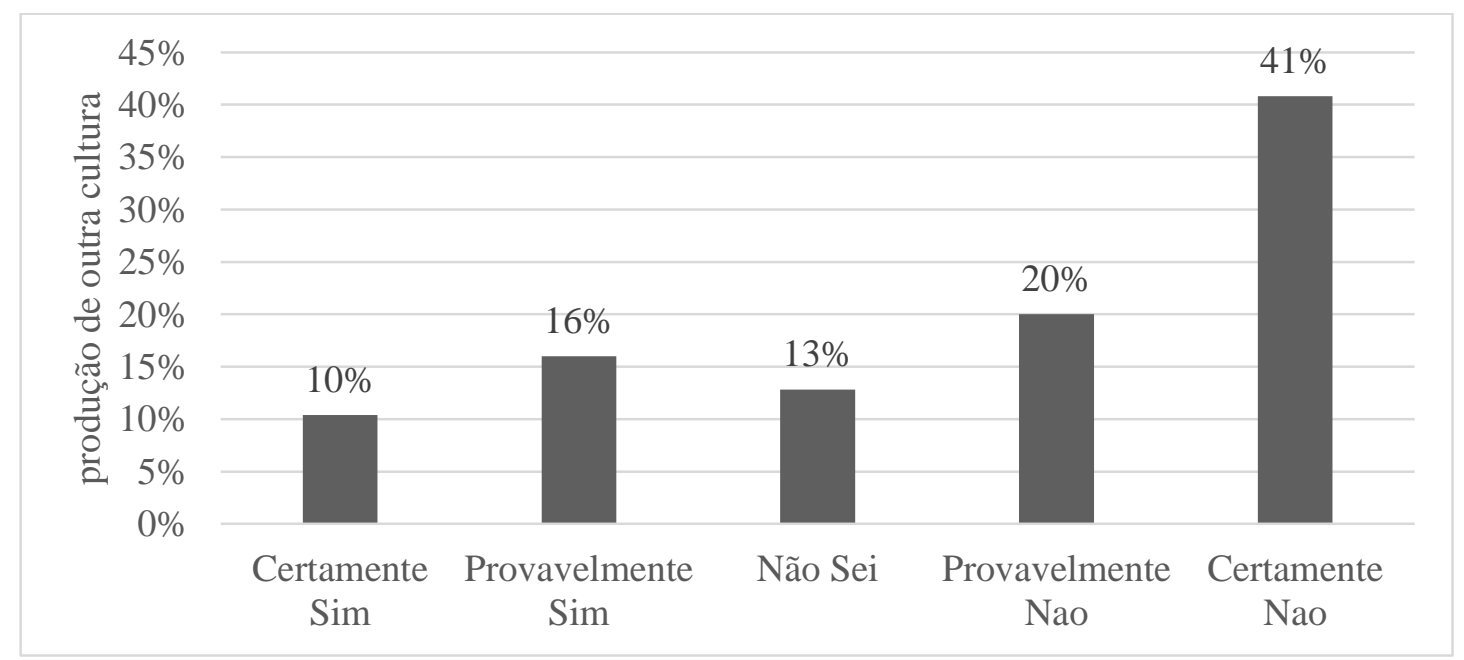

Fonte: Elaboração própria (2021). 
O produtor que só tem laranja dentro de sua propriedade, de acordo com os resultados da pesquisa, não está convicto na diversificação em futuros investimentos, não identificando que possuir uma outra cultura pode lhe trazer benefícios, como economias de escopo - aproveitando seus equipamentos e máquinas em uso comum para as culturas. O fato de o produtor ter pouca convicção em plantar outra cultura, como apontado na questão acima, mostra que ele tem uma boa satisfação com a produção da laranja atualmente.

Os produtores, por estratos produtivos, foram questionados se utilizam suas máquinas agrícolas somente na cultura da laranja, ou se fazem uso delas também em outra atividade agrícola, isso quando às possui. $\mathrm{O}$ levantamento da pesquisa captou que poucas propriedades se utilizam desta oportunidade, não fazendo uso da economia de escopo (Figura 10). Em todos os estratos produtivos, pelo menos $70 \%$ dos produtores questionados só usam seus equipamentos na cultura da laranja

Figura 10: Faz uso de máquinas agrícolas só na cultura da laranja?

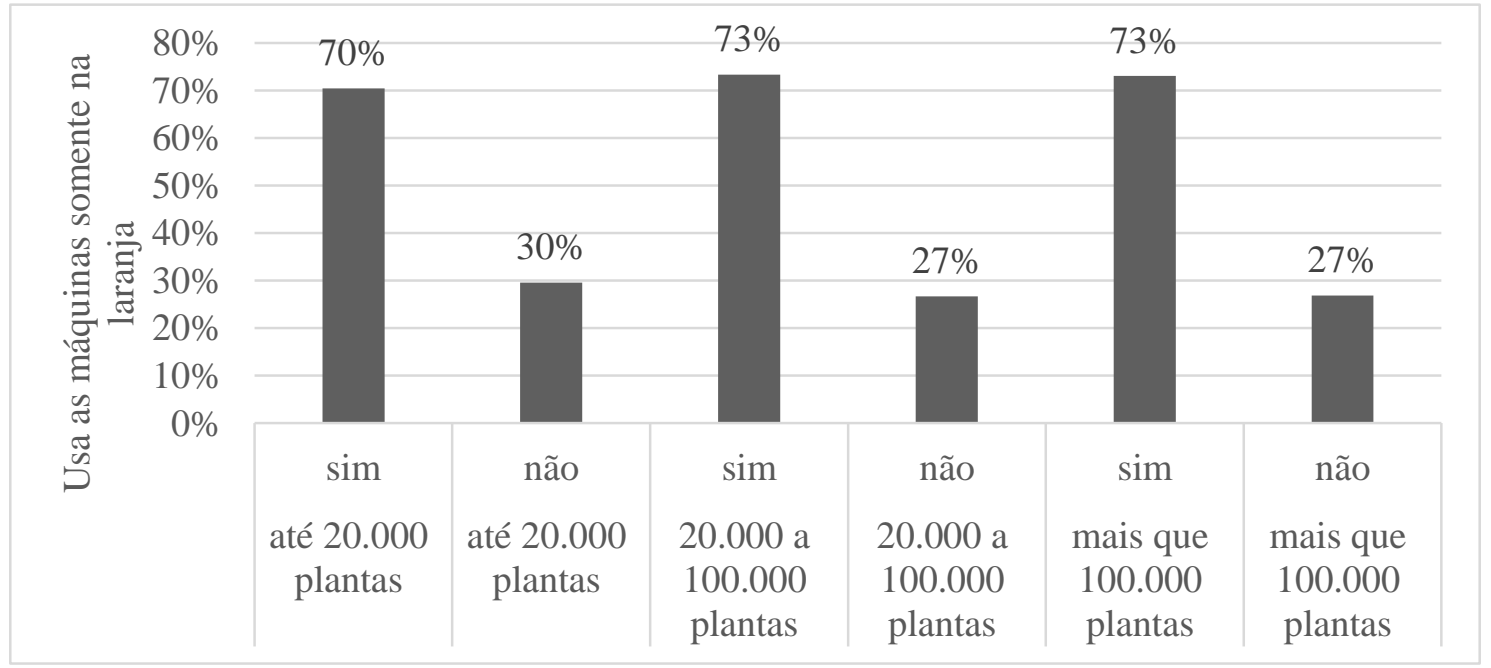

Fonte: Elaboração própria (2021).

Quando uma determinada empresa produz mais de um produto em um local, caracteriza-se a economia de escopo - no intuito de redução dos custos médios dos produtos, sendo fonte de economia de escopo, o uso da mesma máquina para um novo produto a ser fabricado (LOOTY; SZAPIRO, 2002).

Sobre a forma de controle dos ustos de produção, Alcântara (2017), afirma que os produtores paulistas de laranja controlam seus custos de produção por planilha 
eletrônica em computador, em 65,11\% dos entrevistados, e um menor número de produtores $(32,55 \%)$, ainda fazem controle usando através de caderno de anotações. Na pesquisa, os 260 produtores foram questionados como controlam seus custos de produção, nos diferentes níveis de tamanho produtivo. Em se estratificando as propriedades, identifica-se que as de pequeno porte, com até 20.000 plantas, a grande maioria dos produtores controlam seus custos em cadernos, com 62\% (Figura 11). Poucos produtores neste estrato produtivo fazem uso de técnicas mais sofisticadas no controle dos custos de produção.

Figura 11. Formas de controle do custo de produção. Até 20.000 plantas

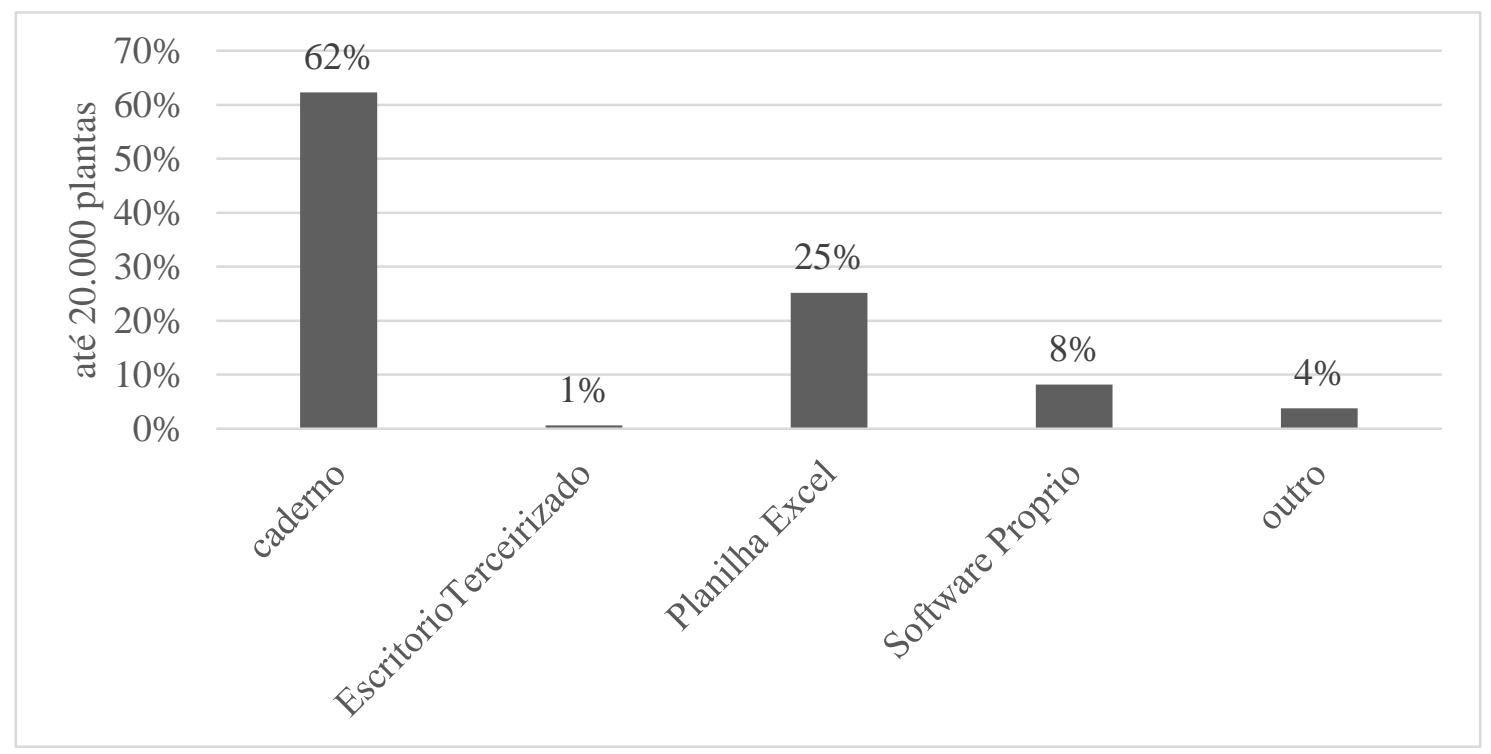

Fonte: Elaboração própria (2021).

As propriedades intermediárias, de 20.001 a 100.000 plantas, em grande parte, utilizam planilhas em Excel e Software próprio para controlar seus custos (Figura 12). O uso de cadernos como forma de controle é bem pouco utilizado pelos citricultores, com $20 \%$ das respostas. 
Figura 12. Formas de controle do custo de produção. 20.001 até 100.000 plantas

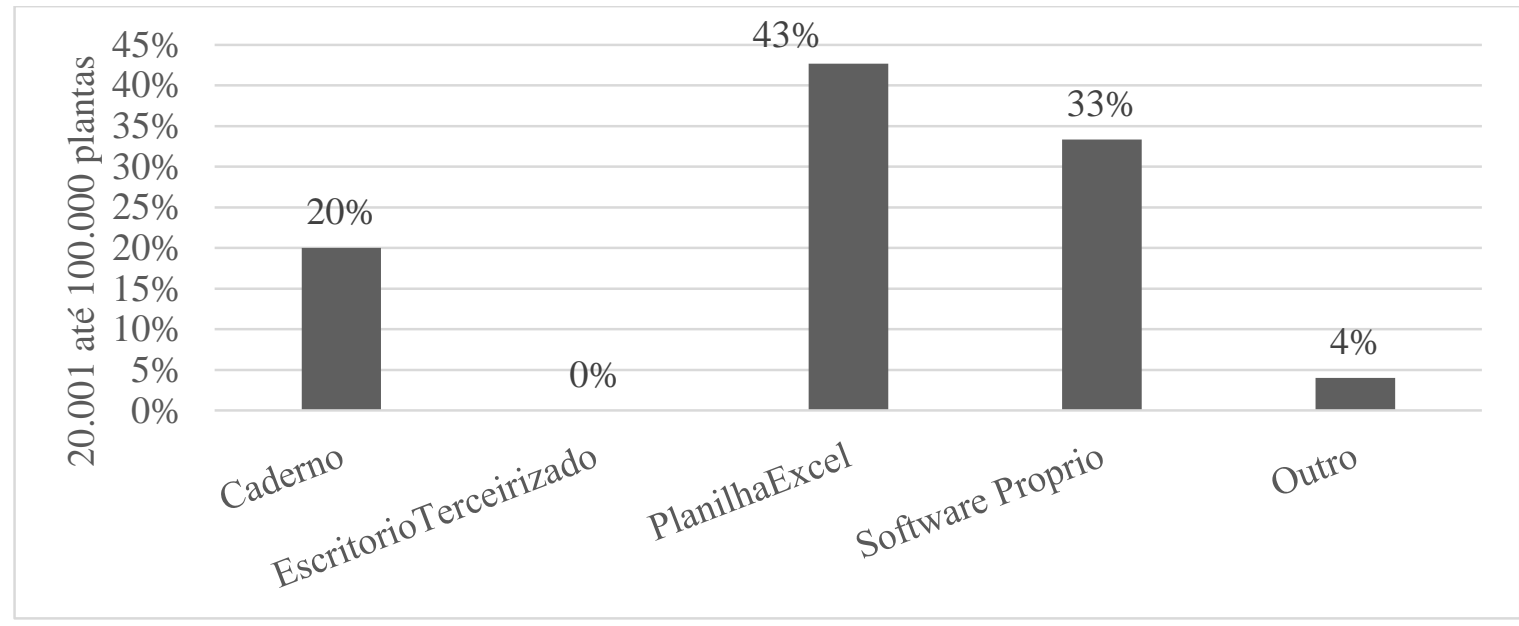

Fonte: Elaboração própria (2021).

Os produtores que possuem imóveis agrícolas (propriedades) com mais de 100.000 plantas fazem uso de métodos mais sofisticados no controle de seus custos planilha em Excel e Software próprio representam $81 \%$ das formas de controle de seus custos. O uso do caderno é muito baixo, em $11 \%$ destas propriedades questionadas (Figura 13).

Figura 13. Formas de controle do custo de produção. Maior que 100.000 plantas

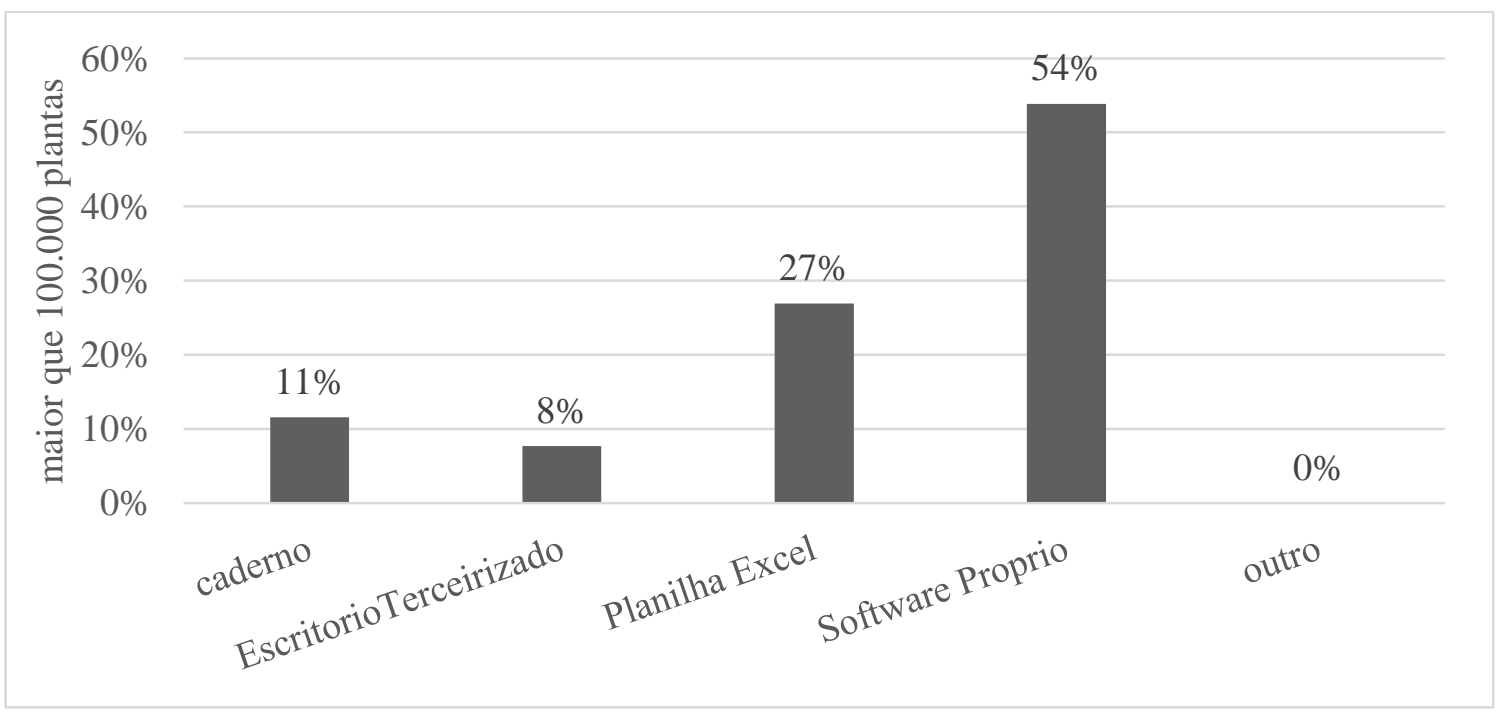

Fonte: Elaboração própria (2021).

A pesquisa identificou a percepção do produtor de laranja com relação à rentabilidade da laranja frente a outras culturas concorrentes nas últimas 3 safras (2017, 
2018 e 2019). Foi efetuada uma afirmação para o produtor (Figura14). A soma dos que concordam fortemente e parcialmente que a laranja foi mais rentável que as outras culturas de sua região, o percentual salta para $88 \%$ de aprovação. Apenas $3 \%$ discordam fortemente que a laranja foi melhor que uma outra cultura.

Figura 14. A laranja foi mais rentável que as culturas concorrentes nas últimas 3 safras

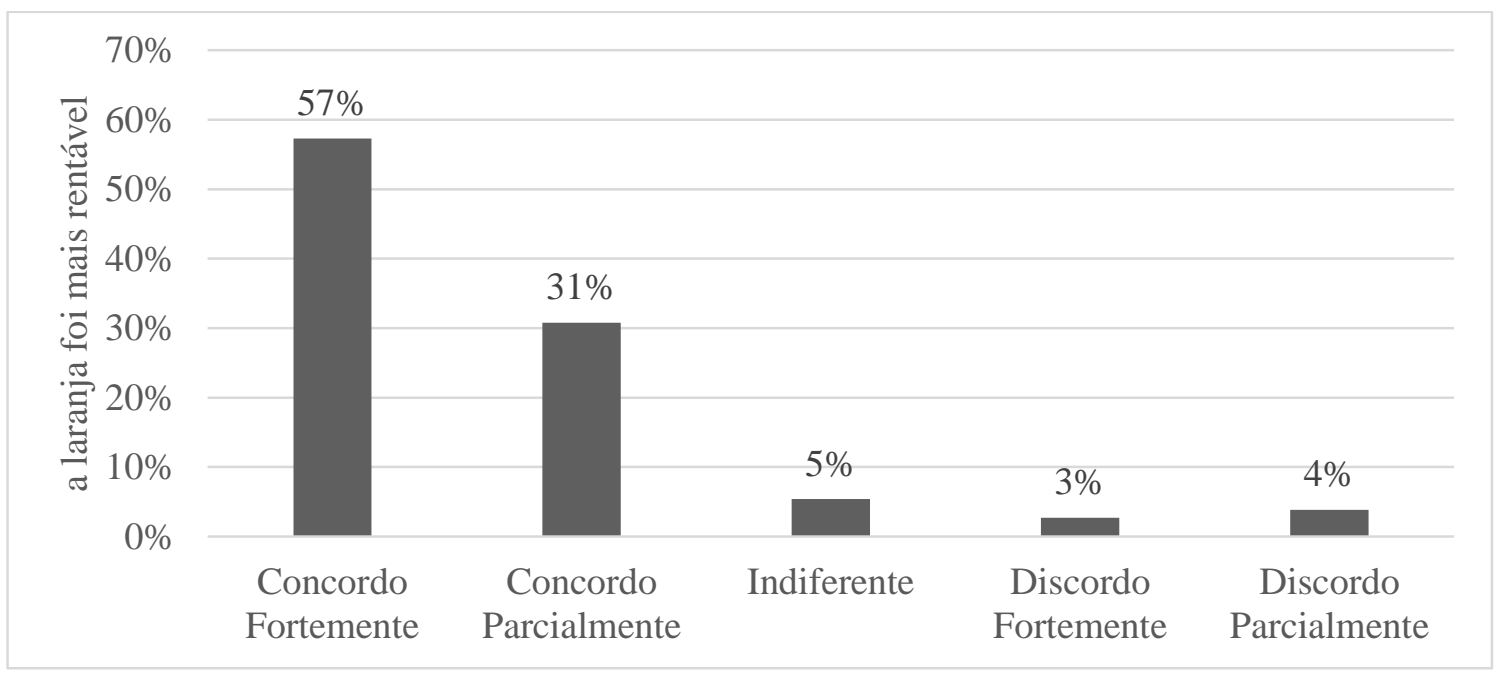

Fonte: Elaboração própria (2021).

Ao serem questionados se substituiriam a laranja por outra cultura, $48 \%$ dos produtores responderam que certamente não substituiriam a laranja por outra cultura. Somente 5\% dos produtores se posicionaram em ter certeza em trocar a laranja por outra cultura (Figura 15).

Figura 15: Substituiria a laranja por outra cultura?

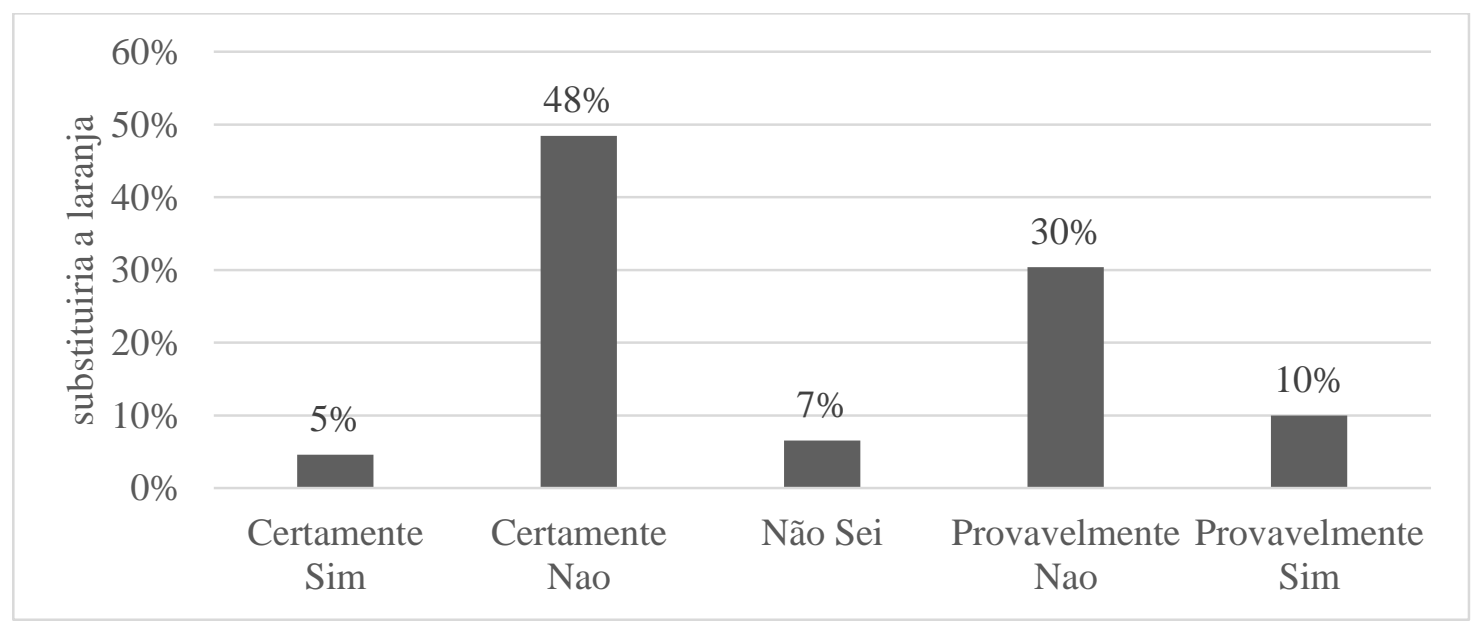

Fonte: Elaboração própria (2021). 
Independentemente se o produtor fosse substituir (trocar) a laranja por outra cultura, ele foi questionado qual cultura ele optaria em eventual troca. As preferências das culturas por região dentro do cinturão citrícola estão apresentadas em percentual na Tabela 1. Identifica-se que as regiões ao Norte do Estado de São Paulo como a de Bebedouro e São José do Rio Preto, apresentam uma vocação, através das percepções dos produtores, de migrar para a cana-de-açúcar, em uma possível troca da laranja. Regiões ao Centro do Estado, sobretudo Matão e Duartina também apresentam a cultura da cana de açúcar como primeira opção do produtor em eventual troca pela cultura cítrica.). Produtores pertencentes as regiões do Triângulo/Sudoeste Mineiro (T.Sud/Mineiro) e Altinópolis tem preferência em eventual troca por outras culturas - não listadas no questionário.

Tabela 1: Culturas preferenciais pelos produtores em substituição a laranja por região.

\begin{tabular}{lccccccc}
\hline Região/Cultura & $\begin{array}{c}\text { Cana-de- } \\
\text { açúcar }\end{array}$ & Milho & Soja & $\begin{array}{c}\text { Outras } \\
\text { frutas }\end{array}$ & $\begin{array}{c}\text { Outra } \\
\text { cultura }\end{array}$ & Seringueira & Total \\
\hline Altinópolis & -- & -- & -- & -- & $75 \%$ & $25 \%$ & $100 \%$ \\
Avaré & $9 \%$ & $8 \%$ & $50 \%$ & -- & $33 \%$ & -- & $100 \%$ \\
Bebedouro & $37 \%$ & $4 \%$ & $4 \%$ & $22 \%$ & $32 \%$ & $1 \%$ & $100 \%$ \\
Brotas & $38 \%$ & $12 \%$ & -- & -- & $50 \%$ & -- & $100 \%$ \\
Duartina & $46 \%$ & -- & $15 \%$ & $8 \%$ & $31 \%$ & -- & $100 \%$ \\
Itapetininga & $14 \%$ & -- & $86 \%$ & -- & -- & -- & $100 \%$ \\
Limeira & $35 \%$ & $7 \%$ & $17 \%$ & $10 \%$ & $31 \%$ & -- & $100 \%$ \\
Matão & $59 \%$ & -- & -- & $8 \%$ & $33 \%$ & -- & $100 \%$ \\
Porto Ferreira & $22 \%$ & $6 \%$ & $16 \%$ & -- & $56 \%$ & -- & $100 \%$ \\
T.Sud/Mineiro & $14 \%$ & -- & -- & -- & $86 \%$ & -- & $100 \%$ \\
São J.R Preto & $51 \%$ & $3 \%$ & $12 \%$ & -- & $16 \%$ & $18 \%$ & $100 \%$ \\
Votuporanga & $25 \%$ & $5 \%$ & $15 \%$ & $15 \%$ & $40 \%$ & -- & $100 \%$ \\
\hline
\end{tabular}

Mediante os dados captados pela pesquisa, o produtor que possui laranja dentro do cinturão citrícola não está disposto no momento a trocar a laranja por outra cultura, contudo, em eventual troca, a cultura da cana de açúcar tem a preferência. Culturas concorrentes à laranja de ciclo perene, como outras frutas e seringueira tiveram uma menor preferência que a cana de açúcar. Importante considerar que a cana de açúcar foi a cultura preferencial para os citricultores do cinturão citrícola quando optaram por substituir a laranja nas últimas décadas (NEVES e LOPES, 2005; FELIPE, 2008; 
AGUIAR e SOUZA, 2014; MAÇONARO, 2017).

\section{Considerações finais}

$\mathrm{Na}$ pesquisa fica evidenciado que os produtores de maior tamanho, além de possuírem maior grau de sofisticação no controle dos seus custos de produção, possuem maior produtividade de laranja por hectare, portanto mais eficientes e com maior chance de continuarem em sua atividade. Contudo, identifica-se que o parque citrícola do principal cinturão produtor brasileiro é ainda dominado numericamente por pequenos produtores de laranja - em um modelo sócio - econômico mais apropriado para uma citricultura mais justa e sustentável. Governo e iniciativa privada devem promover ações para que este modelo continue, de maneira que pequenos citricultores continuem à produzir laranja, empregos e renda.

Apesar da cultura da laranja dentro do cinturão citrícola estar perdendo terreno nas últimas décadas, seja em área, como também em número de propriedades, sobretudo para a cultura da cana -de- açúcar, a pesquisa aponta que esta tendência pode estar em processo de declínio, visto que as fazendas que possuem laranja, e que apresentam áreas em equilíbrio com outras culturas, não pretendem trocar (substituir) a produção da laranja, em sua maioria, por outra cultura. Esta tendência é corroborada pela percepção do produtor de que a cultura da laranja foi mais rentável que as culturas concorrentes nas últimas 3 safras, e que fez investimentos no intuito de ter a máxima produção possível. Portanto, o efeito substituição da laranja por outra cultura pode estar em um período de arrefecimento. Mesmo assim, na percepção do produtor, a principal cultura concorrente à laranja dentro do cinturão citrícola ainda é a cana de açúcar, sobretudo nos setores Norte e Centro do Cinturão Citrícola. Neste espaço geográfico é forte a presença de usinas de açúcar e álcool, o que contribuiu na troca da laranja pela cana-de -açúcar nas últimas décadas.

A cultura da laranja tem um perfil gerador de empregos por hectare maior que a cana de açúcar, soja e milho (cereais) sobretudo pelo fato que sua colheita é essencialmente manual, em detrimento a cana e cereais que possuem colheita quase que totalmente mecanizada. Este fato associado a satisfação dos produtores pela remuneração da laranja nas últimas safras - revelado pela pesquisa - tende a impulsionar uma 
citricultura com maior crescimento econômico nos próximos anos, gerando mais empregos e maior contribuição aos indicadores sociais da principal região produtora de laranja do país.

\section{REFERÊNCIAS}

AGUIAR, J.; SOUZA, P. M. Impactos do crescimento da produção de cana-de-açúcar na agricultura dos oito maiores Estados produtores. Revista Ceres, Viçosa, v. 61, n. 4, p. 482-493, 2014. Disponível em: <http://dx.doi.org/10.1590/0034-

737X201461040006>.Acesso em: 10 jan. 2019.

BUSSAB, W.; MORETTIN, P. A. Estatística básica. São Paulo: Saraiva, 2002. p. 255275.

CAMARA, M. R. G.; CALDARELLI, C. E. Expansão canavieira e o uso da terra no Estado de São Paulo. Estudos Avançados, São Paulo, v. 30, n. 88, p. 93-116, 2016. Disponível em: <http://dx.doi.org/10.1590/s0103-40142016.30880008>. Acesso em: 10 set. 2018.

CATI - Coordenadoria de Assistência Técnica Integral. Levantamento censitário das unidades de produção agropecuária do Estado de São Paulo. 2018. Disponível em: <http://www.cati.sp.gov.br/projeto lupa/>. Acesso em: 29 maio 2018.

CITRUS BR - Associação Nacional dos Exportadores de Sucos de Laranja. Estatísticas de exportação. 2018. Disponível em:

<http://www.citrusbr.com/mercadoexterno/?me=01>. Acesso em: 5 nov. 2018.

DE CAMARGO, A. M. M. P.; CAMARGO, F. P.; CAMARGO FILHO, W. P. Ocupação do solo na agropecuária paulista e a composição da produção vegetal, 1996 e 2008. Informações Econômicas, São Paulo, v. 41, n. 5, p. 84-93, 2011.

ERPEN, L.; MUNIZ, F. R.; SOUZA MAORAS, T.; ROCHA TAVANO, E. C. Análise do cultivo da laranja no Estado de São Paulo de 2001 a 2015. Revista Ipecege, Piracicaba, v. 4, n. 1, p. 33-43, 2018. Disponível em: <https://doi.org/10.22167/r.ipecege.2018.1.33>. Acesso em: 10 maio 2018.

FAO - Food and Agriculture Organization of the Unite Nations. Orange production. Rome, 2016. Disponível em: 〈http://www.fao.org/faostat/en/\#data/QC〉. Acesso em: 25 fev. 2018.

FELIPE, F. I. Dinâmica da agricultura no Estado de São Paulo entre 1990 e 2005: uma análise através do modelo shift share. Revista de Economia Agrícola, São Paulo, v. 55 , n. 2, p. 61-73, 2008.

FUNDECITRUS - Fundo de Defesa da Citricultura. Inventário de árvores e estimativa da safra de laranja no cinturão citrícola de São Paulo e 
Triângulo/Sudoeste Mineiro, 2018/2019. 2018. Disponível em:

<https://www.fundecitrus.com.br/pdf/pes_relatorios/2018_05_21_Invent\%C3\%A1rio_e _Estimativa_do_Cinturao_Citricola_2018-2019.pdf>. Acesso em: 05 nov. 2018.

FUNDECITRUS - Fundo de Defesa da Citricultura. Inventário de árvores e estimativa da safra de laranja do cinturão citrícola de São Paulo e Triângulo/Sudoeste Mineiro, 2019/20. Araraquara, Fundecitrus, 2019. p. 30 p.

FUNDECITRUS - Fundo de Defesa da Citricultura. Inventário de árvores e estimativa da safra de laranja no cinturão citrícola de São Paulo e Triângulo/SudoesteMineiro2020/2021.2020.Disponível.em: $<$ https://www.fundecitrus. com.br/pdf/pes_relatorios/2020_06_25_Invent\%C3\%A1rio_e_Estimativa_do_Cinturao _Citricola_2020-20211.pdf.>Acesso em: 15 dez.2020.

GALINARI, G. Plantios de cana-de-açúcar crescem em áreas de citricultura em São Paulo. 2015. Disponível em: <https://www.embrapa.br/busca-de-noticias//noticia/3394545/plantiosde-cana-de-acucar-crescem-em-areas-de-citricultura-emSãoPaulo>. Acesso em: 06 nov. 2018.

IBGE - Instituto Brasileiro de Geografia e Estatística. Sistema IBGE de recuperação automática - Sidra 2018. Produção agrícola municipal. 2018. Disponível em: <https://sidra.ibge.gov.br/pesquisa/pam/tabelas>. Acesso em: 23.set. 2020.

LOOTTY, M.; SZAPIRO, M. Economia de escala e escopo. In: KUPFER, D.; HASENCLEVER, L. (Orgs.). Economia industrial. 9. ed. Rio de Janeiro: Elsevier, 2002. cap. 3, p. $43-70$.

MAÇORANO, R. P. Impacto das mudanças climáticas na dinâmica na citricultura no Estado de São Paulo. 2017. 88 f. Dissertação (Mestrado em Engenharia Agrícola) Faculdade de Engenharia Agrícola, Universidade Estadual de Campinas, Campinas, 2017.

NEVES, M. F.; LOPES, F. F. Estratégia para a laranja no Brasil. São Paulo: Atlas, 2005. 223 p.

NEVES, M. F. A method for demand driven strategic planning and management for food chains (the chainplan method). In: ANNUAL WORLD FORUM AND SYMPOSIUM, 17., 2007, Parma. Anais... Parma: Agro-Food Chains, 2007.

NEVES, M. F.; TROMBIN, V. G.; MILAM, P.; LOPES, F. F.; CRESSONI, F.; KALAKI, R. O retrato da citricultura brasileira. 1. ed. São Paulo: Citrus Br, 2010. $137 \mathrm{p}$.

OLIVEIRA, A. F. M. Impactos dos preços sobre a oferta canavieira no Estado de São Paulo entre 1995 a 2015. 2017. 77 f. Dissertação (Mestrado em Administração) Universidade Estadual Paulista, Jaboticabal, 2017. 
PAULILLO, L. F; NEVES, M. C. Análise das estruturas de governança de compra de laranja dos maiores packing houses no Estado de São Paulo: um estudo multicasos sobre arranjos híbridos. Organizações Rurais \& Agroindustriais, Lavras, v. 17, n. 4, p. 461-478, 2015.

PELISSON, G.V.; DE DAVID, C. As sucessivas expansões das monoculturas de café, laranja e cana-de-açúcar do município de tabapuã/sp e a resistência da agricultura familiar. In: ENCONTRO NACIONAL DA ANPEGE, 11., 2015, Presidente Prudente. Anais...Presidente Prudente: Anpege, 2015.

Disponível em: <http://www.enanpege.ggf.br/2015/anais/arquivos/9/290.pdf〉. Acesso em: 07 ago. 2018.

PULCINE, P. R.; SIMÃO, A. C. A.; MANOLESCU, F. M. K. Análise do mercado da laranja. 2017. Disponível em: <http://biblioteca. univap. br/dados/INIC/cd/inic/IC6\% 20anais/IC6-31.PDF>. Acesso em: 15 jun. 2018.

UAGRO. O Brasil é o maior produtor mundial de laranja. 2013. Disponível em: <http://www.uagro.com.br/editorias/agricultura/laranja/2013/08/07/brasil-e-o-maiorprodutor-mundial-de-laranja.html>. Acesso em: 18 ago. 2018.

Recebido em 08/03/2021.

Aceito para publicação em 19/09/2021. 